\title{
Solving the problem of concentration of agricultural lands by agricultural holdings from the perspective of rural development
}

\section{Oleg Gorb}

\author{
University of Dąbrowa Górnicza, \\ Zygmunta Cieplaka 1c, 41-300 Dąbrowa Górnicza, Poland \\ PhD, Professor
}

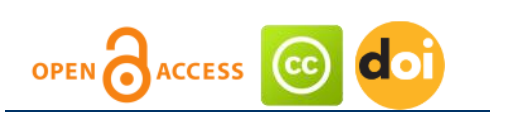

Article history:

Received: September 10, 2017

1st Revision: October 1, 2017

Accepted: October 25, 2017

\section{JEL classification:}

Q15

Q56

Q57

R11

\begin{abstract}
The development of rural areas largely depends on the activities of local agricultural enterprises. It is expedient to consider the impact of agricultural holdings on the development of rural areas, taking into account that in recent years more and more agricultural commodity producers are joining vertical-integrated companies. A lot of land and investment resources are fixed there. Currently, agricultural holdings are dynamically increasing the agricultural production and meeting demands of the internal and outer food markets of Ukraine.
\end{abstract}

Keywords: agricultural holdings, local agricultural enterprises, rural areas, rural development.

\section{DOI:}

\section{Introduction}

The decline of rural areas is one of the most painful socio-economic problems in Ukraine nowadays. Since the announcement of independence in 1991, the legislative acts regulating the development of both agricultural sector and the state economy in general considered the socioeconomic renewal of the rural areas. Different frameworks, strategies and development programs to increase the economic and social standard of living in rural areas are being developed at different levels of management with the efforts of state authorities and research institutions. Despite the considerable efforts and resources spent on the development of rural areas, systematic results were not achieved. The agricultural sector (by a purely economic point of view) became a matter independent of rural areas, which historically were and still are related to agriculture (from social and environmental point of view) (Shanin, 2015).

It should be noted that the reform of land matters in Ukraine, ongoing for several decades, also largely aims to uphold rural areas. As scientists aptly note, agricultural holdings have recently 
become an economy in itself (Lutsenko \& Kropivko, 2013). The growing influence of holding companies in the agrarian sector of Ukrainian economy encourages the scientific community to indepth research of various aspects of this trend.

The problem of the formation and activity of agricultural holdings in Ukraine became the subject of scientific research for many economists, among them I.I. Lukinova, Yu.O. Lupenko, P.T. Sabluk, V.O. Volovik, S.I. Demyanenko, N.P. Zarytska, V.D. Zalizko, V.G. Andriychuk, V.I. Boiko, V.P. Vasylenko, A.E. Dankevych, O.V. Krysalnyi, P. Kulinich, A.G. Mazur, M.Y. Malik, V.Yu. Urkevych, V.V. Yurchyshyn, O.V. Shanina, B.I. Shuvar, V.M. Yatsenko.

The main aim of the article. The analysis of impact of the development of agricultural holdings on the position of rural areas is an important line of scientific research.

\section{Presentation of the main research}

The scientists point out that the small-scale agricultural enterprises cannot really compete with other agricultural commodity producers, including foreign ones, due to the lack of reliable channels for material supply and distribution of final products and shortness of financial resources for the modernization of production equipment and introduction of innovations (Shuvar, 2015).

On the contrary, the large integrated associations such as agricultural holdings gain impressive economic results, though the actual impact on indicators of living standards and welfare of rural areas remains insignificant.

The creation and activity of agricultural holdings is regulated by the Law of Ukraine "On Holding Companies in Ukraine". Art. 1 of the Law states, that a holding company is a joint-stock partnership that owns, uses and disposes of corporate stockholdings (stakes, shares of stocks) of two or more corporate enterprises. N.P. Zarytska points out that "the main way of formation [of agricultural holdings] ... was the injection of domestic or foreign capital of non-agricultural origin in the processing industry with further development of distribution and of agriculture for the selfsufficiency of basic stores" (Zaritska, 2010).

Setting up holding companies in the rural sector of the Ukrainian economy caused the problem of concentration of agricultural lands by a singular economic entity. This situation impacted the prospects of the development of rural areas inventing a new research context for the activity of agricultural holdings, significant for many scientists and businessmen (Gorb, Yasnolob, Dedukhno, \& Kaliuzhna, 2017).

For example, P. Kulinich analyzes the sales of rights to lease land for agricultural purposes. The author points out that "the powerful incursion of agricultural holdings takes place using lease rights during the moratorium of the sale of agricultural land", emphasizing that "all landholdings of agricultural holdings are based on agricultural land lease agreements" (Kulinich P., 2014). The researcher concludes that the agricultural holdings negatively impact even the prospects of market turnover development of agricultural land and the formation of the agricultural farm sector.

Volovyk O.A. reached same critical conclusions about the negative influence of agricultural holdings on the development of land relations. She notes that "after 2004, the large-scale concentration of land tenure system began, manifesting in the increase of leased land, the creation of new agricultural holdings [which are] vertically and horizontally integrated structures with land areas that reach tens and hundreds of thousands of hectares, monopolizing the international trade benefits of agricultural products and food" (Volovyk, 2012). Analyzing the agricultural holdings as business entities in the agrarian sector of economy, the author emphasizes their negative impact on rural development: "Cleverly using the legal tax privileges and preferences for agriculture, these economic structures bag the value that should have become the source for reconstruction of used natural and social resources in the rural area and for improving the quality of the local living environment, but in fact the value is "washing away" from the village".

By now, it is undeniable fact that agricultural holdings increase the land tenure through mergers and acquisitions of traditional agricultural enterprises. At the same time, the concentration of agricultural land by agricultural holdings does not depend on whether the companies retained limited liability partnership or became private enterprises or units of new companies.

In 2016, 5.85 million hectares, which is almost $28 \%$ of all Ukrainian agricultural land, were used by agricultural enterprises controlled by agricultural holdings. In comparison with last year, the total land bank of holdings decreased by 0.19 million hectares. However, the fraction of land in use increased from $27.4 \%$ to $27.9 \%$ (Fig. 1) due to the exclusion of the Crimean agricultural land. In general, due to the annexation of Crimea, the total land bank of holdings decreased by at least 125 thousand hectares.

The territorial analysis of the agricultural land concentration by agricultural holdings is equally impressive. Again, the leader is the UkrLandFarming agricultural holding, cultivating farmlands in 23 regions of Ukraine (its largest managed areas are more than 50 thousand hectares, 
located in Poltava and Sumy regions according to detailed map of the assets of that agricultural holding on its official site.

Figure 1: Land Bank of Ukraine's Agricultural Holdings, 2009-2016

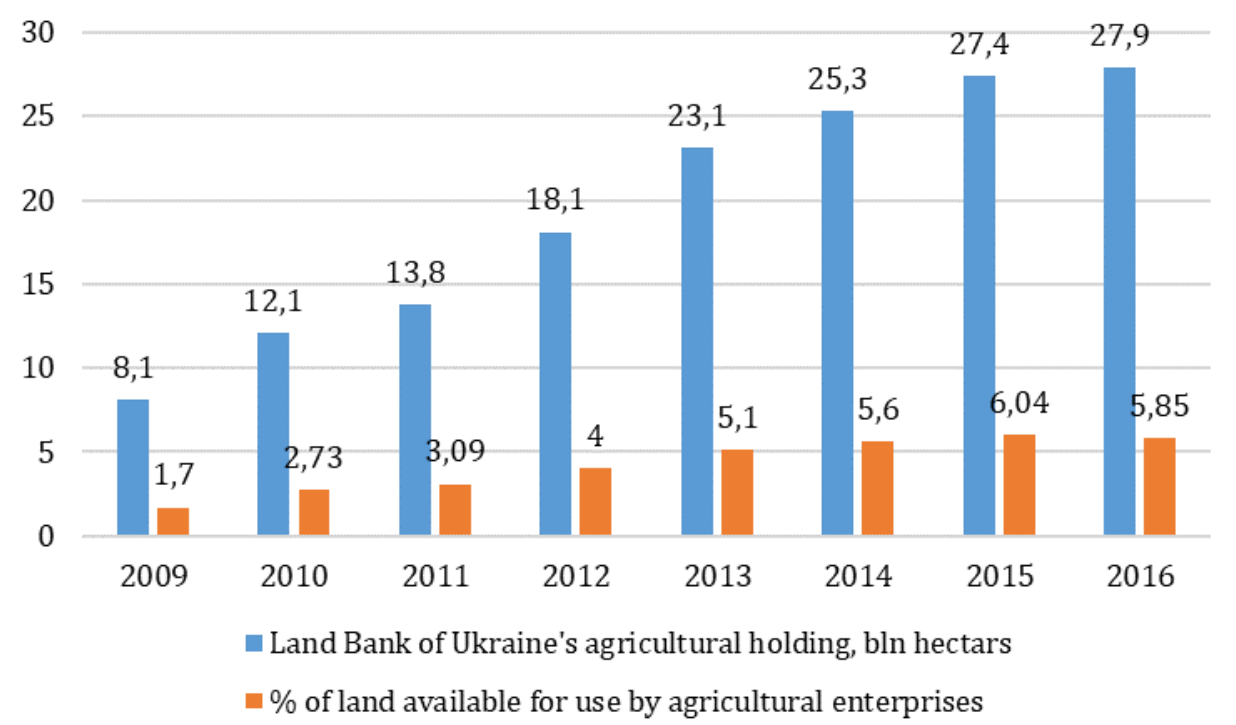

Source: (Shuvar, 2015)

Thus, for the period of 2014-2016 the agricultural holdings of Ukraine continued with the trend for concentration of agricultural land. Furthermore, in regions with fertile black soil these companies were the most active in the formation of land banks.

The agricultural enterprises grow, and the agricultural land is concentrated in plots of 16.154 hectares (Agrotech-Garantia Ltd.), 6875 hectares (TOV (LLC) UkrLatAgro), 5809 hectares (TOV (LLC) Savynitsi), and 4102.3 hectares (TOV (LLC) "Promin-Pryvat"). Of those organizations, only the enterprises of "Pryvat-Agro" are in livestock production.

But as for today, it is really problematic to fully evaluate the whole scale of agricultural lands rented by such structures, as the official statistics do not reflect many aspects of this phenomenon.

Additionally, the non-transparent relations in the integration structures make the possibility of any cooperation with executive authorities and local self-government much more difficult (Aranchiy, Yasnolob, Makhmudov, \& Radionova, 2017). In fact, the heads of agri-industrial development departments of the district state administration sometimes do not even know the name of the main enterprise that branched to Myrhorod district and leases the agricultural lands there. The imperfection of data on the activities of agricultural enterprises included in agricultural holdings can be to some extent represented as a pyramid (on an example og the subordination of agricultural enterprises included in "Pryvat-Agro" agricultural holding in Myrhorod district) (Fig. 2).

Figure 2: A fragment of the subordination "pyramid" of agricultural enterprises that are part of the agricultural holding "Pryvat-Agro"

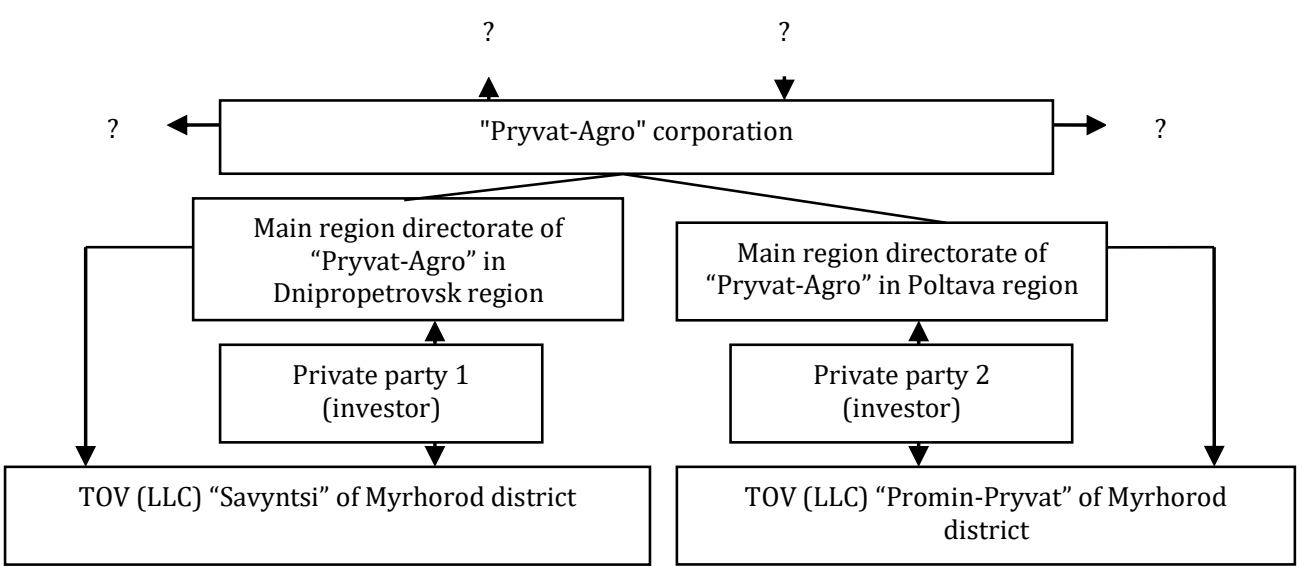

Source: author's product 
Even not counting the activities of agricultural holdings, there is a direct link between the well-being of the community of rural areas and the efficient management of rural commodity producers. In this case, it seems quite logical for rural areas to count on creation of new working positions for local residents and increased revenues from tax payments for the budget, as well as to expect improvements in infrastructure development. As it was indicated by S.I. Demyanenko, such expectations are based on the fact that "the founders of these enterprises are rural inhabitants, and they and their family members use this infrastructure: means of communication, medical, cultural and educational institutions (children go to nursery school and school, community center, library etc.)". A similar "scheme" of expectations could be realized upon condition of the economy management of typical agricultural enterprises, such as agricultural TOV (LLC), private farm enterprises, cooperatives. It seems that upon condition of agricultural holding's activity, the wellbeing of rural areas should grow accordingly to the large-scale usage of agricultural land, which is typical for such companies.

Nevertheless, the real situation is the opposite. The explanation is the lack of legal norms regarding any social obligations of agricultural holdings to the community of rural areas. Often, the founders of agricultural holdings live in another place and neither they nor members of their families use rural infrastructure, which does not contribute to the development of rural infrastructure as a result (Yasnolob \& Radionova, 2017) There is a policy of social responsibility in some agricultural holdings, they have statutes on social partnership, social programs etc., but this is not typical for all companies. In most cases, this practice is reduced to PR-actions and is not realized on a system basis.

Zalizko V.D. determined several negative consequences of this process in his research of the agricultural holdings influence on the socio-economic development of rural areas (Zalizko, 2013). The negative consequences, both for social relations and environmental safety, are directly related to the problem of concentration of agricultural land by agricultural holdings. Thus, the negative social consequences of the agricultural holdings activities in the rural area are:

- $\quad$ hyper-capitalization of land banks of agricultural holdings, which may lead to the loss of control by rural community over the major part of agricultural land. In addition, there is a low percentage of fees paid for the use of land shares to landlords;

- an increase of unemployment rate among rural community due to the extrusion of laborintensive agricultural products and the transition to mono-production while using singlepurpose agricultural machinery.

It should be noted that agricultural holdings require highly skilled specialists to operate modern equipment of foreign production. However, the labor force available in rural areas does not meet these requirements due to skill level. For retrenchment, the agricultural holdings do not intend to invest money in the trainings of local specialists but hire workers with professional education (obtained at their own or at the state expense) from other regions. In practice this approach leads to increasing unemployment in the rural areas both among those with an educational level and among those who have higher education and are highly qualified.

The negative impact of the activities of agricultural holdings in the environmental field was described by scientists. This impact is even more significant because the inhabitants of rural areas remain alone while trying to cope with the consequences of this influence. Budgets of rural communities are not able to handle financing of environmental activities. Only regional level programs, if properly financed from the state budget, will be powerful enough to counteract it.

Demyanenko S.I., having thoroughly analyzed the impact of agricultural holdings on the development of agriculture in Ukraine concludes: "It should be noted that a number of agricultural holdings bear the expenses to support the social infrastructure of the rural area. However, due to the fact that agricultural holdings are registered legally in cities foremost, they pay almost no taxes to local budgets of rural areas. Former collective agricultural enterprises which have lost the status of a legal entity have become branches or divisions of agricultural holdings. This is of course a disadvantage for rural areas. Therefore, it is necessary to introduce a mechanism that would ensure the payment of taxes by agricultural enterprises and organizations not at the place of registration of their main company, but at the place of activity of their agrarian units, in rural areas. This will allow the rural councils to accumulate funds for local budgets and to develop the social infrastructure of the rural area" (Demianenko, 2008).

Therefore, in order to organize the joint activity of all the agricultural enterprises (agricultural holdings especially), local governments and communities of villages and settlements, we suggest using the specially designed interaction mechanism working on the partnership basis (Fig. 3). 
Figure 3: Model of strategic planning for the progress of cooperative and corporate structures on the basis of development of rural territories

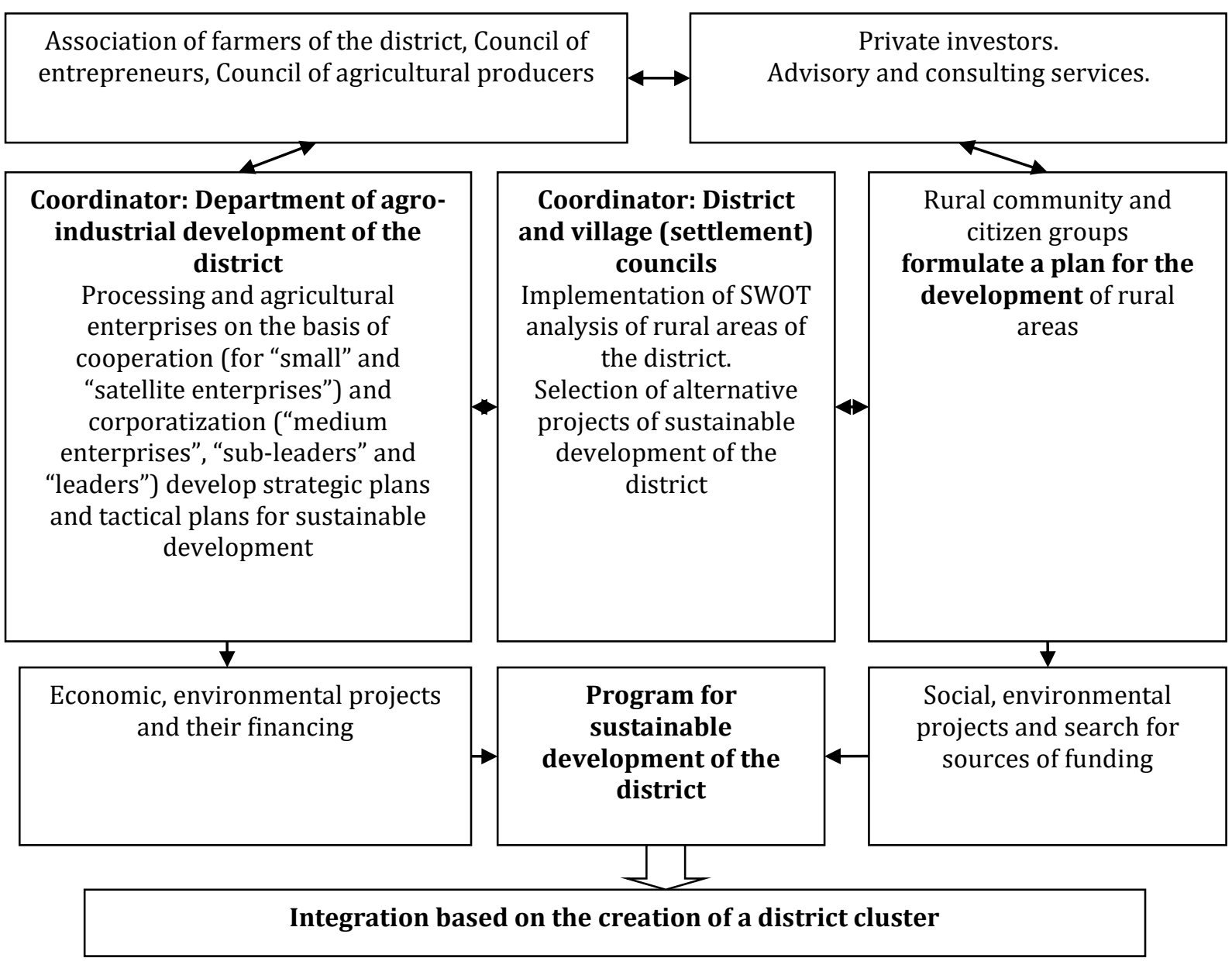

Source: author's product

Thus, it is useful for small producers to unite in cooperatives and to develop business plans of economic development. This will provide the possible attraction for the population of rural areas. Corporative formations should be directed to horizontal diversification.

On the basis of increasing profitability it is expedient for all the enterprises to make allocations for social development of the projects submitted by communities of villages and settlements. The district and village (settlement) councils should become the integrator of the two poles at the district level. In order to encourage agricultural enterprises and investors to participate in the implementation of the projects, we propose to substantiate the obligations of state authorities in its implementation for each project.

Implementing a coupled specialization in the land-hungry labor-intensive crop and livestock production would be useful, as would be establishing the joint economic activity with the mechanism of cooperation and clusterization based on the social support of rural areas for the development of business strategies and programs for most of the small businesses ("small enterprises", "satellite enterprises").

We suggest for agricultural holdings to develop environmentally oriented agro-industrial production, hone the social orientation of their activities and to act as integrators of joint economic activity. It would be useful to recommend creating the informational and social policy departments in agricultural holding companies that will further the financial solution of the most urgent issues in the areas of education, medicine, spirituality, landscape designing of rural areas territories, etc. via entering the agreement of social responsibility with the head of village council conjointly with local governments and local communities.

Such proposals must be regulated by clear legislative framework that will enable the state to control the activities of agricultural holdings.

Therefore, to increase social orientation in agricultural holdings it is expedient:

- to develop Programs for social investment aimed at financial assistance of the most important projects initiated by territorial communities; 
- to generate funds for the sustainable development of rural areas, and to direct $100 \mathrm{UAH}$ from each hectare of leased land to this fund;

- to make annual deductions from the social development fund to the territorial fund of the community for social services (water, roads, electricity, etc.), the expenditures plan should be based according to the size of land;

- $\quad$ to closely cooperate with agrarian universities and create joint training centers;

- to oblige the chief-managers of agricultural enterprises to live in the territory where the land of relevant agricultural enterprise is located.

In order to attract young prospective specialists to the agricultural production and support the locals, we propose to oblige to create favorable conditions for the recruitment of young promising specialists to the agricultural production and support of in-migrants. It is also useful to provide young families with housing accommodations.

\section{Conclusions}

The development of agricultural holdings in Ukraine and the analysis of the activity of several vertically integrated agricultural enterprises in Myrhorod district of Poltava region reveal their strong economic development concurrent with the significant socio-environmental decline of rural areas where the enterprises are managing.

Therefore, it is necessary to tighten the state control over the activity of agricultural holdings to involve them in sustainable development of rural territories in future. It is necessary to introduce a mechanism that would provide the funding for the implementation of community projects at the place of activity of agrarian units of corporations. At the same time, the state should instill proper conditions for the creation of cooperatives as an alternative to further limiting the land ownership for large corporate structures.

Thus, agricultural enterprises which are part of agricultural holding companies accumulate significant resources of agricultural land and should develop and operate only when the sufficient level of socio-economic life in rural areas is ensured.

\section{Appendix A. Supplementary material}

Supplementary data associated with this article can be found, in the online version, at https://dx.doi.org/10.14254/jems.2017.2-2.8.

\section{Funding}

The authors received no direct funding for this research.

\section{Citation information}

Gorb, 0. (2017). Solving the problem of concentration of agricultural lands by agricultural holdings from the perspective of rural development. Economics, Management and Sustainability, 2(2), 79-85. doi:10.14254/jems.2017.2-2.8.

\section{References}

AgriSurver (2017). The largest agroholdings of Ukraine. Retrieved from https://docviewer.yandex.ua.

$\begin{array}{lllll}\text { Agroprosperis } & \text { (NSH). } & \text { (2017). } & \text { Latifundist.com. } & \text { Retrieved }\end{array}$ http://latifundist.com/rating/top100/27938-new-century-holding.

Aranchiy, V., Yasnolob, I., Makhmudov, H., \& Radionova, Y. (2017) Conceptual foundations of the organisation of innovative activities at agro-industrial enterprise based on outsourcing and The Business Process Model and Notation. Economic Annals-XXI, 165(5-6), 84-89. doi:10.21003/ea.V165-18.

Demianenko, S.I. (2008). Agroholdings in Ukraine: is it good or bad? German-Ukrainian Agriculture Dialogue. Kyiv, Institute of Economy Research and Political Consults. Retrieved from http://www.ier.com.ua/files/publications/Policy_papers/Agriculture_dialogue/2008.

Gorb, O., Yasnolob, I., Dedukhno, A., \& Kaliuzhna, Y. (2017). The Formation of the Management System of Ecological, Social, and Economic Development of Rural Territories Using the Experience in European Union. Journal of Environmental Management and Tourism, 8(3), 516-528. doi:10.14505/jemt.v8.3(19).03. 
Kulinich, P. (2014). The agricultural land market in Ukraine: Will it be able to function on the leasung rights. Legal Journal, 4. http://www.justinian.com.ua/article.php?id=4068.

Lutsenko Yu. O., \& Kropivko M. F. (2013). Agroholdings in Ukraine and their increased socially aware activities. Economics of AI, 7, 5-21.

Shanin, O. V. (2015). The concept of village-forming enterprise in the framework of development of rural territories. Effective Economy, 4, 18-28.

Shuvar, B. I., \& Pidgrebelna, M. I. (2015). The specifics of activity of large-scale agricultural enterprises and their influence on the agrarian market of Ukraine. Ukrainian Black Sea Region Agrarian Science, 1, 58-64.

Volovyk, O.A. (2012). Concerning the causes of the traditionality in a number of archaic forms of management in Ukraine: an institutional approach. Journal of the Academy of Advocacy of Ukraine, 4, 1-6.

Yasnolob, I., \& Radionova, Y. (2017). The organizational fundamentals of innovation development management of agro-industrial enterprises. Economics, Management and Sustainability, 2(1), 60-66. doi:10.14254/jems.2017.2-1.5.

Zalizko, V.D. (2013). Influence of holding formation of agricultural enterprises on socio-economic development of rural areas. Economics of Ukraine, 6, 71-78.

Zaritska, N. P. (2010). Retrospective of the agroholdings development in Ukraine through the prism of management. The development of agribusiness in Ukraine: problems, priorities, perspectives: Proceedings of the Ukrainian scientific conference devoted to the 10th anniversary of the department of agricultural management (Ukraine, Zhytomyr, March 25-27, 2010). Zhytomyr: I. Franko ZhDU.

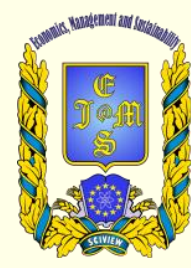

() 2016-2017, Economics, Management and Sustainability. All rights reserved. This open access article is distributed under a Creative Commons Attribution (CC-BY) 4.0 license.

You are free to:

Share - copy and redistribute the material in any medium or format Adapt - remix, transform, and build upon the material for any purpose, even commercially.

The licensor cannot revoke these freedoms as long as you follow the license terms.

Under the following terms:

Attribution - You must give appropriate credit, provide a link to the license, and indicate if changes were made.

You may do so in any reasonable manner, but not in any way that suggests the licensor endorses you or your use.

No additional restrictions

You may not apply legal terms or technological measures that legally restrict others from doing anything the license permits.

Economics, Management and Sustainability (ISSN: 2520-6303) is published by Scientific Publishing House "CSR",

Poland, EU and Scientific Publishing House "SciView", Poland

Publishing with JEMS ensures:

- Immediate, universal access to your article on publication

- High visibility and discoverability via the JEMS website

- Rapid publication

- Guaranteed legacy preservation of your article

- Discounts and waivers for authors in developing regions

Submit your manuscript to a JEMS at http://jems.sciview.net or submit.jems@sciview.net

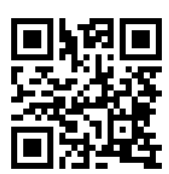

